\title{
On the Development of some British Echinoderms.
}

\author{
By
}

\section{Dr. Th. Mortensen, Copenhagen.}

With Figures 1-15 in the Text.

For several years I have felt the desire of going to Plymouth in order to gain practical knowledge of the excellent methods for rearing pelagic larvæ of marine animals, which have been worked out there, especially by the Director of the Marine Biological Laboratory, Dr. E. J. Allen. I was therefore very glad to receive last year an invitation from Dr. Allen to come and stay some time at his laboratory, and having got a grant for this purpose from the Carlsberg Fund and from the Danish Government, I had at length the desired opportunity.

The time I spent in Plymouth-from June 10th to July 15th this summer (1913) —was long enough for learning the methods, but, unfortunately, too short for having the full profit of my rearings, because several of the larvæ take a longer time to reach their full size and still more to pass through metamorphosis. However, the results attained are not unimportant.

No less than six different species of Echinoderms were reared to a more or less advanced stage of development, according to the date at which fertilization could be undertaken, and according to the rate of growth of the different larval forms. These six species are: Asterias glacialis, Luidia ciliaris, Ophiactis Balli, Ophiocoma nigra, Spatangus purpureus, and Holothuria nigra. Fertilization of Echinocardium flavescens was also undertaken, but unfortunately the whole culture was destroyed by an accident, and no máterial was got later on of the species. Some other forms, the development of which I wanted likewise to study, e.g. Echinocardium pennatifidum, Amphiura (Ophiocnida) brachiata, Ophiopsila aranea, were not ripe at that time or sufficient material could not be got.

The main purpose of these studies on the larval development of different Echinoderms-which I hope to have the opportunity of continuing during a planned voyage to the Pacific-is to find the characteristic features of the larval forms and to see if the larvæ have any bearing on the

NEW SERIES.-VOL. X. No. 1. NOVEMBER, 1913. 
classification of the full-grown animals. The embryological development in itself is not at present the object of my researches, and in the present report, therefore, only occasionally pure embryological facts are given.

As I had, of course, not much time to study the living larvæ more closely, having so many different cultures going on at the same time, I preserved material of the different developmental stages for study later on. On examining the preserved larvæ after my return to Copenhagen I found that a very regrettable mishap had occurred. The alcohol in which the larvæ were kept had in some way or other become acid, and the skeleton of all the larvæ had been dissolved. As the specific characters are especially found in the skeleton in those larvæ which are provided with such, the value of my material had thus been considerably diminished. Fortunately I had made a preparation in Canada balsam of the larva of Ophiactis Balli while still in Plymouth, so that in this case nothing was lost.

After I left the laboratory my cultures were looked after for some time by the attendant, Mr. Smith, and some of the later stages were sent me. In this way I got the later stage of the Luidia larva; a few larvæ of Spatangus purpureus, with the skeleton preserved, also came to hand, but in so poor condition that only little use could be made of them. Of the other larvæ only a few of $A$. glacialis were obtained, but these were not in a more advanced stage than that reached before I left the laboratory.

\section{I.-Asterias glacialis.}

The development of this species has never been satisfactorily worked out, in spite of the fact that it is one of the objects commonly used in experimental embryology. A. Russo, in his paper "Contribuzione all" embriologia degli Echinodermi e sviluppo dell' Asterias glacialis O. F. Müller,"* describes the first developmental stages, until the formation of the vibratile chord. Having reached this stage the larvæ began to degenerate. Some later stages, which were caught pelagically, were also referred by Russo to this species (his figures 22-25) ; it is, however, evident enough that they cannot belong to this species-the strong development of the vibratile chord at the anterior end of the frontal (or preoral) area, where the brachiolarian processes appear later on in the Asterias larva, is sufficient proof that they cannot belong to an Asterias. In my Echinodermenlarven der Plankton Expedition (p. 30), I have given the name Bipinnaria Russoi to this larva. The rearing of the more advanced stages of the $A$. glacialis larva has given the definite proof that

\footnotetext{
- Boll. d. Soc. di Naturalisti in Nayoli, Ser. I, Vol. VII (1892).
} 
I was right then in maintaining that these later stages figured by Russo could not belong to $A$. glacialis.

The most important and interesting contribution to the development of $A$. glacialis has been given by Yves Delage, who has reared parthenogenetic larvæ of this species to full size and beginning metamorphosis.* In spite of this it is still very desirable to make further studies of the normal development of this species. One can, of course, not be sure beforehand that the parthenogenetic larvæ are quite like those normally developed. Further, the figures given by Delage are partly not very satisfactory. In fact, it still remains uncertain what the specific characters of this larva are, by which it may be distinguished from other Asterias larvæ, or whether, perhaps, such characters do not exist, so

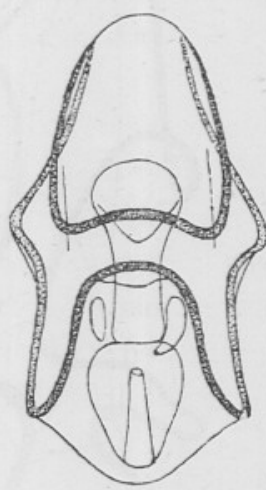

Fig. 1.



Fig. 2.

Figs. 1-2.-Bipinnaria of Asterias glacialis, seven days old. 1, front view ;

2 , side view ; e, enterocol vesicle. 100/1.

that this larva could not be distinguished with certainty from other Asterias larvæ, for instance that of $A$. rubens.

I was very glad then to have the opportunity already on the second day (the 12th June) after my arrival at the laboratory of making an artificial fertilization of $A$. glacialis. The fertilization was very successful, about 95 per cent of the eggs being fertilized. The culture went on excellently, the larvæ being fed with the diatom Nitzschia from Dr. Allen's cultures. However, I did not succeed in obtaining the fully developed larval form. Delage found that the rate of growth of his parthenogenetic larvæ was comparatively slow, and I had the same experience with the normal larvæ.

The differentiation of the vibratile chord began after five days, and after

* Yves Delage, "Élevage des larves parthénogénétiques d'Asterias glacialis" (Arch. de Zool., expér. et gén. (4), II, 1904, pp. 27-46.) 
seven days (the 19th) the stage represented in Figures 1-2 was reached. For the next two weeks there was no further differentiation, and I nearly gave up the hope of getting it to proceed in its development, thinking that the diatoms were perhaps not suitable food for this larva; indeed, I found that the diatoms ejected by it had the same colour as those which had not been swallowed, so it appeared that the larvæ could not digest the diatoms. But on the 4th July I found some specimens in which the left enterocœl vesicle had begun to grow forwards, and now the development went on continually. On the 7 th July the enterocœl

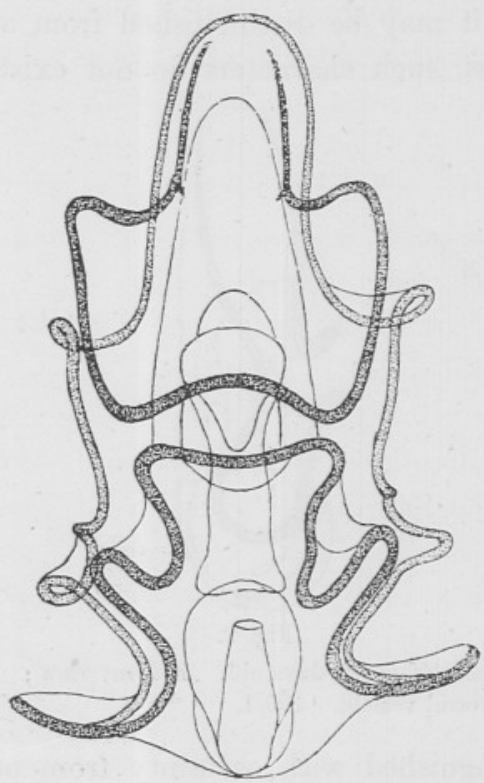

Fig. 3.



Fig. 4.

Figs. 3-4,-Bipinnaria of Asterias glacialis, four weeks old. 3 , front view ; 4 , side view. $80 / 1$.

vesicles had united in the preoral lobe, and the long processes had begun to develop. The stage represented in Figures 3-4 was reached on the 9th July. When I left Plymouth, on the 15th, no essential advancement beyond this stage could be observed, and a few larvæ sent to me later on were not in a more advanced stage either. I am thus unable to give definite information of the specific characters of the fully developed larva.

Judging from the figures given by Delage, the larva of $A$. glacialis differs from the larva of $A$. rubens and vulgaris, the only two other species known to which it is similar, in the sucking dise at the basis of the brachiolarian processes being surrounded by a complete ring of small 
papillæ, while in the two other species there are only 2-3 papillæ at each side of it (cp. text Figs. 4-6 of Delage's paper). Also the crown of the brachiolarian processes appears to afford a good specific character, there being 2-3 circles of small papillæ on a thickened ring, while in the other species there is only a single circle of papillæ at the tip and no thickened ring. If this proves to hold good for the normally developed larva of A. glacialis, it will be easily distinguishable from the other species. A number of larvæ which were taken in the Plankton at Plymouth all had only 2-3 papillæ at each side of the disc, and the crowns consisting of a single circle of papillæ; they should accordingly all belong to $A$. rubens, which may be possible, since also some few ripe specimens of this species were found. In any case, it is very desirable to have the $A$. glaciatis larva reared to its full size, so that we may be able to see, with certainty, by which characters it differs from the $A$. rubens and $A$. vulgaris larvæ. As the species $A$. glacialis is not so very closely related to the other two species mentioned, one would expect the larvæ likewise to be distinct enough.

In the Echinodermenlarven der Plankton Expedition (p. 43), I have distinguished, under the name of Bipinnaria lavis, an Asterias larva found by Joh. Müller at Elsinore, which differs from the $A$. rubens larva in having no dorsal median process. I suggested that this larva might belong to $A$. glacialis, as there are found only three Asterias species in the Sound (between the Kattegat and Baltic), i.e. A. rubens, Mülleri and glacialis, the latter being, however, very rare here. The larvæ reared by Delage would seem to show that the dorsal median process is as well developed in the Bipinnaria of $A$. glaciatis as in those of $A$. rubens and vulgaris, and then the $B$. lavis can only be an abnormal larva of $A$. rubens. I have never observed such specimens among the numerous larvæ of this species which $\mathrm{I}$ have seen.

The culture of the $A$. glacialis larvæ showed the interesting feature that a large number of the larvæ, about 50 per cent of them, had either two dorsal pores, one for each enterocœl vesicle, or the vesicles were united across the stomach, having one single, median pore (Figures 5-6). This feature has also been observed by Goette* in the larva of the same species. G. W. Field, in his paper "The Larva of Asterias vulgaris" $\dagger$ (pp. 110-111), describes the formation of two pore canals in the young A. vulgaris larva as a normal feature, while the presence of two pore canals has otherwise been regarded as pathological. Field found the two

* Goette, "Bemerkungen zur Entwicklungsgeschichte der Echinodermen" (Zool. Anzeiger, 1880, p. 324 . Fig. 2).

+ Quart. Journ. Micr. Sci., N.S., 34, 1893. 
pores persisting only a short time, the right being closed again 8-12 hours after its formation. Though I have not paid attention to this on examining the living larvæ, I think I can say definitely that the formation of two pore canals is not a normal process in the larva of $A$. glacialis. In the larvæ which I preserved on the 16th June, at 9 p.m., the enterocœl vesicles have not been formed; in those preserved on the 17th, 10 a.m., they are formed, and the left vesicle alone has a pore. It is certainly very improbable that the pore of the right vesicle should then already have disappeared completely; this process would in that case go much faster than Field has found it in A. vulgaris. It seems to me that the

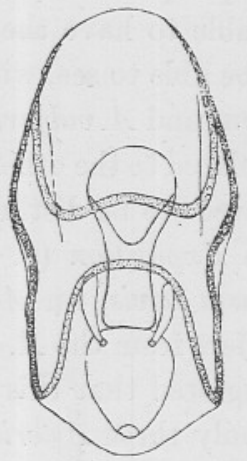

Fig. 5 .

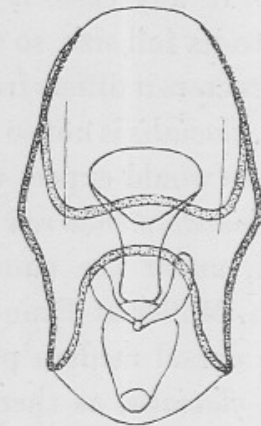

Fig. 6 .

FIgs. 5-6.-Bipinnaria of Asterias glacialis, showing abnormal formation of dorsal pores. Seen from the dorsal side. 100/1.

facts here produced rather tend to show that what Field has found is an abnormality. In any case the two pores in the $A$. glacialis larva represent an abnormality. To enter on a discussion of the possible phylogenetic importance of the two dorsal pores is not the place here.

I must also mention the observation that the larvæ of this species, as well as of all the other species reared, in swimming rotate around their longitudinal axis, always turning to the left. In the Spatangus and Ophiactis larvæ this rotation ceases along with the development of the long processes; in the other larvæ it had not ceased in the most advanced stages observed.

\section{II.-Luidia ciliaris.}

This species at first caused me a good deal of trouble. Both females and males were found with ripe genital products, but the spermatozoa did not move. Being myself not familiar with experimental work on fertilization, I asked Mr. J. Gray, who was working at the laboratory, 
for advice. He suggested that we might try to raise the alkalinity of the water by adding some drops of sodium hydroxyde $(\mathrm{NaOH})$. This proved excellent. The spermatozoa at once began to move, and then the fertilization succeeded completely. It was already at a rather late point of time, the 27th June, so that it could not be expected to get the complete development of this species; still a good deal was reached, and as this is the first time a Luidia has been reared, the observations are of some interest.

The cleavage is unequal, the relative size of the two first cleavage cells being, however, somewhat variable. The blastula has the same remarkable character as is described by Masterman for Henricia sanguinolenta,* and by Gemmill for Solaster endeca, $\uparrow$ the cell layer forming



Fig 7.

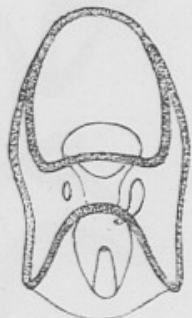

Fig. 8 .

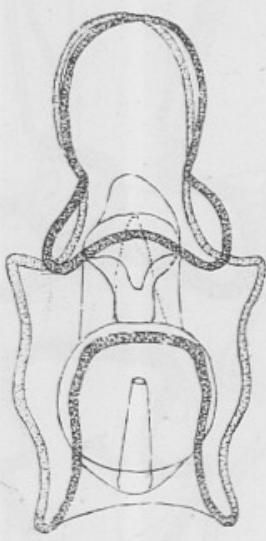

Fig. 9.

Fias. 7-9.-Bipinnaria of Luidia ciliaris. 7, five days old ; 8 , six days old ; 9, eighteen days old. Front view. 100/1.

irregular folds. The gastrula is rather elongate and large; this stage is reached on the third day. After five days the larvæ begin to assume the shape of small Bipinnariæ (Fig. 7); the enterocœl vesicles have formed, but the vibratile chord is not yet differentiated at the anterior end. The next day, the 3rd July, the vibratile chord was complete (Fig. 8). The most advanced stage to which the larvæ reached before I left Plymouth is represented in Figure 9, from the 14th July. The processes have begun to appear, and the preoral lobe has begun to assume the characteristic elongate shape of the Luidia larva; the enterocœl vesicles have united in the preoral lobe.

After my return to Copenhagen I had the pleasure to receive a couple

* A. T. Masterman, "The early development of Cribrella oculata (Forbes), with remarks on Echinoderm development" (Trans. R. Soc. Edinburgh, Vol. XL, 1902). See especially Plate l, Fig. 17.

+ James F. Gemmill, "The development of the starfish Solaster endeca (Forbes)" (Trans. Zool. Soc., London, XX, 1912). 
of larvæ from the same culture, preserved by Mr. Smith, on the 1st August, being thus a little over one month old. They are represented in Figures 10-11. Here the shape of the Luidia larva, so characteristic through the elongated preoral part and the long median processes, is easily recognized. The length of the larva is now $1 \mathrm{~mm}$. Still the development is not sufficiently advanced for showing definitely by which characters

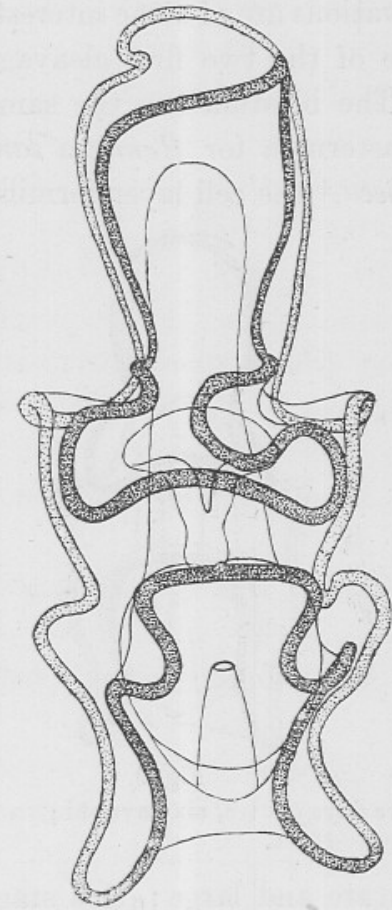

Fig. 10.

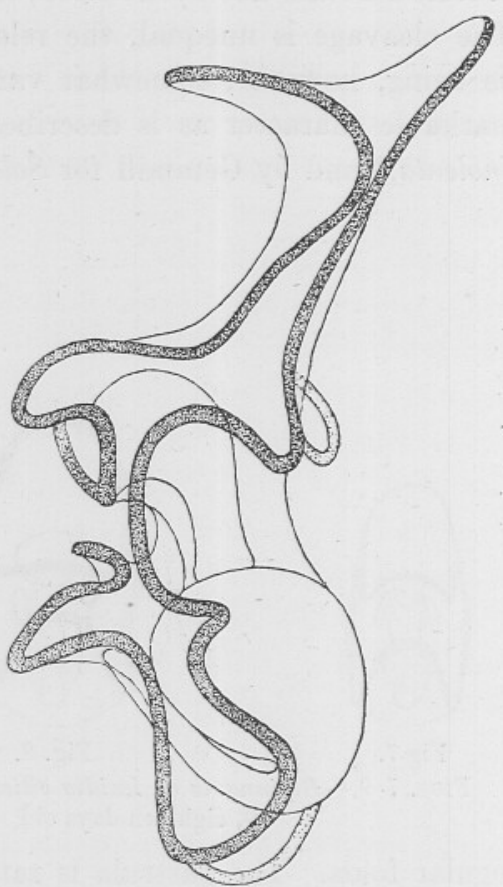

Fig. 11.

FIGs. 10-11.-Bipinnaria of Luidia ciliaris, five weeks old; 10, front view ; 11 , side view. $100 / 1$

this larva is distinguished from the Bipinnaria of Luidia sarsi. But it can now scarcely be doubted that the larva figured by Garstang, in his paper "On some Bipinnariæ from the English Channel,"* is really the larva of $L$. ciliaris. This species is very common at Plymouth, while L. sarsi is rare; its breeding season is June to July, and Garstang found the larva in August. I have previously held the opinion that Garstang's larva belonged to $L$. sarsi $; \dagger$ I must now join Ludwigt in the opinion

* Quart. Journ. Micr. Sci., N.S., 35, 1894.

† Echinodermenlarven der Plankton Expedition (p. 40). Nordisches Plankton Echinodermenlarven (p. 11).

I H Ludwig, "Der Asteriden des Mittelmeeres." Fauna $u$. Flor $d$. Golfes v. Neapel, 24 Monogr., 1897 (p. 82). 
that it belongs to $L$. ciliaris. It is, however, still very desirable that this larva should be reared to metamorphosis-and as it has now been found to be easily reared, this will probably soon be done-this large, beautiful larva must, indeed, be a magnificent object for embryological study.

In the Echinodermenlarven der Plankton Expedition (pp. 39-40), I have remarked, in connection with the suggestion made by Hensen that the young larvæ might be fixed, that this conclusion is scarcely justified, because the young larvæ have not yet been found. To this remark Hensen has added the following note (p. 40): "Meine Eusserung lautet: 'Die I. Fahrt brachte 114, die II. 11, und die III. 78 Luidien mit Stern, in Summa 203, deren Diagnose wir Hrn. Mortensen verdanken. Es müssen doch wohl die jüngeren Larven eine festsitzende Lebensweise haben, sonst könnten sie uns nicht entgangen sein.' Da Zahlen beweisen, muss ich an diesem Satz festhalten." Though I have always been quite convinced that the Luidia larva could not have a fixed stage before the free-swimming larval stage, it is quite satisfactory for me that I have now been able to give the definite proof that my opinion, founded on morphological grounds, was right, in spite of Hensen's statistics. To be sure, my observations are made on $L$. ciliaris, while Hensen speaks of $L$. sarsi: but to suppose that of two so very similar larvæ one should be fixed in its first stages, the other free-swimming, would really be too absurd.

It is very remarkable that the larvæ of $L$. ciliaris appear to be comparatively rare at Plymouth. Being impressed with the enormous development of the gonads in this species I have tried to make an approximate calculation of the number of eggs in a large $L$. citiaris. In a specimen of $30 \mathrm{~cm}$. arm length I counted the number of gonads-which are here arranged in a series along each side almost to the point of the arm instead of one large gonad at each side of the basis of the arm as is the rule in Asteroids - and found them to number 150 in each series-300 per arm. As the species is seven-rayed, a complete* female of that size, which is nearly the average, has 2,100 ovaries; these are, however, of somewhat different size, decreasing in size towards the point of the arm. An ovary from about the middle of the arm was divided into a hundred parts of as nearly as possible equal size, and the number of eggs in one part was counted; it was ca. 3,000. This means that in one ovary there are at least ca. 300,000 eggs, probably nearer

* The arms very easily break off, and it is quite difficult to get complete specimens, though such are often seen in the contents of the trawl, before it is hauled on deck. 
half a million. Taking, however, into consideration the decreasing size of the ovaries towards the point of the arm it may be just to take as the mean number of eggs per ovary only 100,000, and for safety we may still reduce the number of ovaries to 2,000. This gives as the number of eggs in a grown female of $L$. ciliaris no less than 200 millions. We might expect from this that this species would be exceedingly common, the larvæ as well as the grown. But the larvæ are only rarely observed, and as for the grown specimens, one may certainly expect to get about half a dozen specimens in each haul with the trawl, and from their large size this makes the impression of a good lot-in

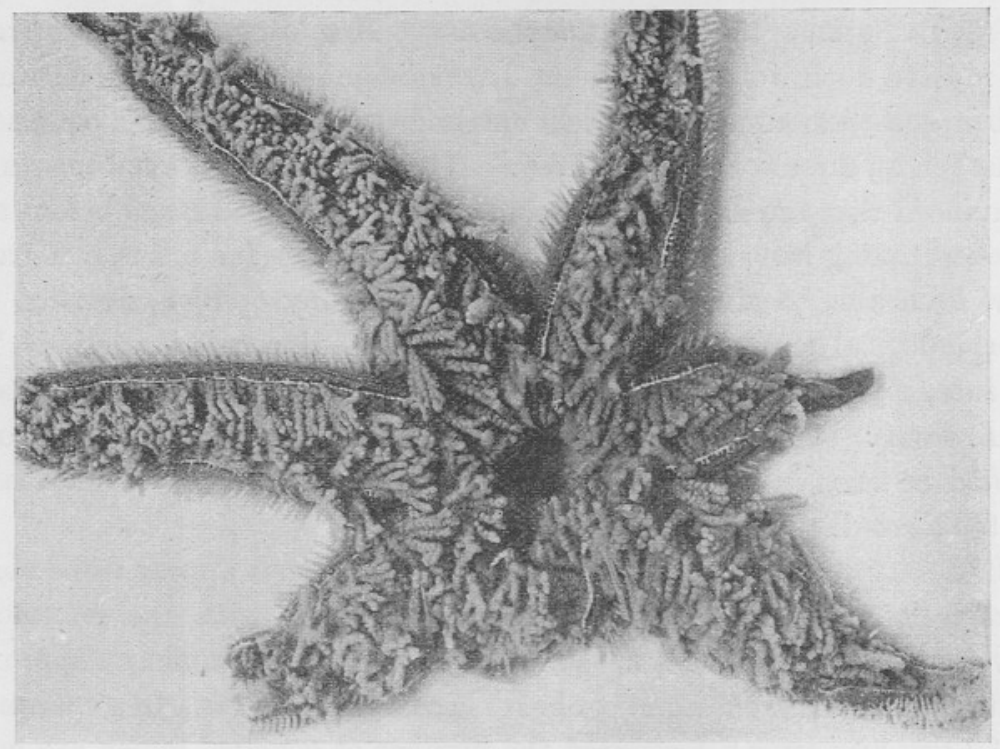

Fig. 12.

FIG. 12,-Female Luidia ciliaris, opened so as to show the genital organs. I/4 of natural size. (From a photograph by Mr. F. Martin Duncan.)

reality this is a very small number, especially compared with Ophiocoma and Ophiothrix, which are generally taken by thousands in each haul. What a waste of eggs must here take place!

In Figure 12 is represented a female of $L$. citiaris opened so as to show the gonads. It gives, however, only a slight impression of the profusion of gonads seen in such a specimen, the more conspicuous on account of the beautiful red colour of the gonads with the ripe eggs.

I may here mention that in this species a distinct sexual dimorphism may be observed, at least in the breeding season. The colour of the 
female is red, that of the male brownish; the rays of the female are somewhat broader than in the male, and upon the whole the male scarcely reaches so considerable a size as the female. It is mostly quite easy to distinguish between the sexes at a glance-quite apart from the fact that generally the arms break so as to expose some of the gonads.

In the stomach of this species I have found remnants of Ophiurids (Ophiothrix).

\section{III.-Ophiactis Balli.}

On the 17th June several specimens of this species were taken on the Eddystone grounds, especially on tubes of Chatopterus and on Ascidians. Some of these were found to contain ripe sexual products; they were placed in a large jar with only a few centimetres of water, in order to try if they would shed their eggs and sperm. Already next day I had the pleasure of finding the fertilized eggs, which had partly already reached the blastula stage ; at 12 o'clock, viz. after scarcely more than eighteen hours, the first swimming blastulæ were observed. On the 19th the embryos were found swimming actively close to the surface of the water ; they were somewhat elongated, a little transparent at one end. On the 20 th the first rudiments of the skeleton were formed, and the posterolateral processes had begun to appear, showing already an indication of red colour at the point. On the 21 st the larvæ had already distinctly the shape of an Ophiopluteus; the antero-lateral and the postoral rods (and processes) had begun to grow out, and likewise the recurrent rod had begun to appear. On the 26th the body skeleton was completely formed, and the three pairs of processes had become somewhat longer, especially the postero-lateral. These latter processes are distinctly red at the point; also the postoral transverse chord has a reddish tint, the larva being otherwise uncoloured. It always swims near the surface, but at this stage does not any longer rotate round its longitudinal axis.

Having reached this stage the development ceased; the larvæ still remained alive for some days, but without showing further advance. Probably the diatoms were not suitable food for them. However, the stage reached is sufficiently advanced for showing the characters of the larva, so that it will be possible to recognize it also in later stages, the essential characters of the Ophioplutei lying in the body-skeleton, which had, fortunately, already reached its full development (Fig. 13).

The main features of it are the following : Recurrent rods are present, whereby two large meshes are formed in each half of the body. The cross-rods are peculiar in being slightly lobed at the end, the lobes of the two rods of each side catching into each other. The end-rods are rather 
long, straight, trifid at the point. The postero-lateral rods are provided with thorns along the inner side, and also the antero-lateral rods are slightly thorny. (These thorns will doubtless be considerably more numerous in the fully developed larva.) It must be pointed out that there is no posterior tuft of cilia; the frontal area is quite small. Otherwise there is nothing to be remarked concerning the shape of the larva,

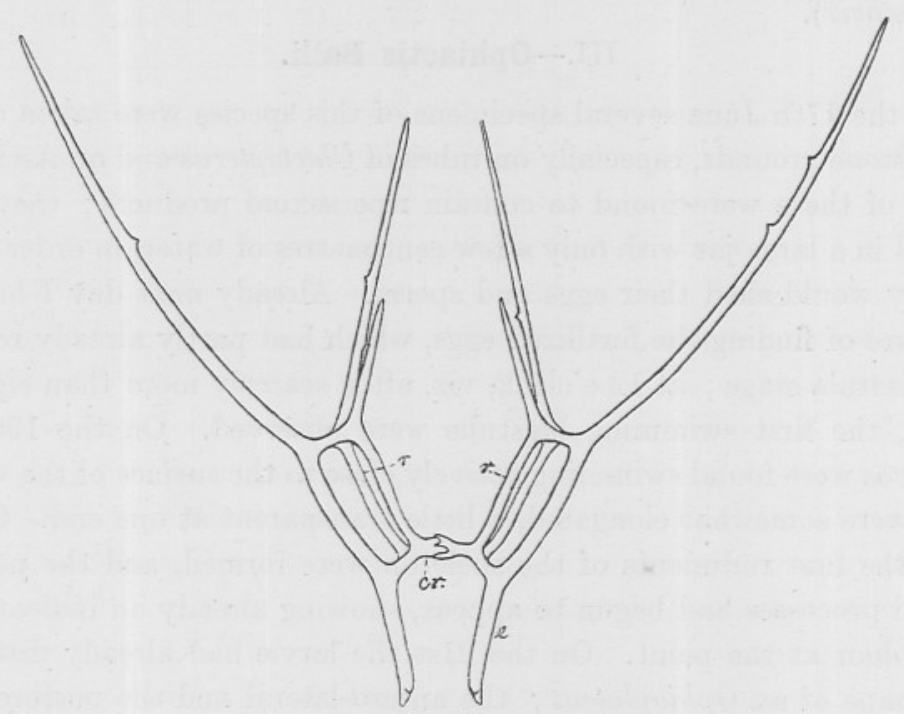

Fig. 13 .

FIG. 13.-Skeleton of the Ophiopluteus of Ophiactis Balli. $c r$, cross-rod ; e, end-rod ; $r$, recurrent rod. $275 / 1$.

in this stage at least; it has the typical Ophiopluteus shape, as appears: from the shape of the skeleton.

It is very satisfactory that the larva of this species could be reared to. a sufficiently advanced stage for recognition, this being the first information of the larval form of a species of the genus Ophiactis. (The two species Ophiactis Kröyeri (L.) and $O$. asperula (Phil.) appear to be viviparous.*)

\section{IV.-Ophiocoma nigra.}

It was not until towards the end of June that this species was found to. contain ripe sexual products. On the 25th June some specimens were put in a jar in the same way as Ophiactis, and the next day some fertilized eggs were found. It was no large number, and I then repeated the experiment, but without success, evidently because the specimens were p. 693 .

* H. Ludwig, "Brutpflege bei Echinodermen." Zool. Jahrbiicher, Suppl. VII, 1904, 
not very ripe. To open the specimens and take out the eggs did not prove good either for the same reason. However, some results were obtained from the eggs got at the first experiment. The development proved to be comparatively slow. The first indication of the posterolateral processes was found on the 30th, i.e. in ca. five days old embryos. The embryos are remarkably elongate, and the oral lobe remains very large after the formation of the said processes. On the 1st July I found the first rudiments of the skeleton. On the 4th July there was seen the first indication of the postoral rod, and the postero-lateral processes had somewhat increased in length-but herewith the development apparently ceased; the larvæ were alive and apparently healthy when I left on the 15th July, but the development was not advanced beyond the stage reached on the 4th. Probably again the food was not suitable.

The development reached a sufficiently advanced stage to show that the body skeleton is simple, without recurrent rod. The cross-rods are thorny. The body skeleton is upon the whole small, the rods short. Unfortunately I can give no figure of it, the skeleton having been dissolved in all the preserved specimens as explained above. The colour is yellow, or at the point of the postero-lateral processes, yellowish green : there is no indication of red pigment.

Though the rearing of this larva was thus not very successful, the results obtained are not without value; from the indications given here it will doubtless be possible to recognize the Ophiocoma larva, when it is found in the plankton. The two Ophiurids, Ophiothrix fragilis and Ophiocoma nigra, are by far the most numerous Ophiurids occurring at Plymouth; they must almost cover the bottom on large areas. The larvæ of both forms must occur in large numbers in the full breeding seasons of the two species. As the larva of Ophiothrix is well known, it must be possible to find out, with the help of the indications given here, which larva belongs to Ophiocoma, and in all probability the larva is already known. In a paper on Loch Sween ("The Glasgow Naturalist," Journ. Nat. Hist. Soc. of Glasgow, IV, 1912) Professor J. Graham Kerr has figured (p. 43, Fig. 4) a very peculiar Ophiurid larva, which agrees with the Ophiocoma larva in having a simple body skeleton and a very large preoral lobe. It occurred in immense numbers at the beginning of August-the season thus being likewise in accordance with the suggestion that it is the Ophiocoma larva. In fact, Graham Kerr himself gives that suggestion, and I think it very probable that he is right. The most conspicuous peculiarity of this larva is the development of four " epaulettes," as I have previously found in a larva from the Bermudas de- 
scribed as Ophiopluteus Henseni in the Echinodermenlarven der Plankton Expedition (p. 62, Pl. VII, 2). The occurrence of a similar-though quite distinct-larva at the Bermudas is not at all against the supposition that the larva figured by Kerr belongs to $O$. nigra, since this genus is also represented at the Bermudas (by the species Ophiocoma echinata (Lmk.) and $O$. pumila (Ltk.).

This larva has also been observed at Port Erin by Dr. H. C. Chadwick, who showed me on my visit there (at the end of July) figures he had made of these and many other Echinoderm larvæ. May we hope that he will soon publish his many beautiful figures and interesting observations on the Echinoderm larvæ? They would doubtless prove of great value to students of these larvæ, which are so interesting from both a morphological and a biological point of view. Even if the larvæ can at present only partly be referred to species, they are, at least most of them, so well characterized that they can be recognized with certainty, and the observations made on the larvæ of hitherto unknown origin are by no means lost, but may be directly transferred to the species to which some such larvæ are later on proved to belong.

\section{V.-Spatangus purpureus.}

This species is one of the very first Echinoderms of which artificial fertilization and rearing of the larvæ were undertaken. It was A. Krohn who did so in Messina in 1853 ("Über die Larve von Spatangus purpureus," Müll. Arch., 1853, p. 253, Taf. VII). He did not succeed in rearing it to metamorphosis, but still so far that he thought he was able to recognize it in free-swimming specimens. In another paper, "Beobachtungen über Echinodermenlarven" (ibid., 1854, p. 208), he gave them some further observations on the structure of this larva, from which it appears that it is characterized especially by the postoral, postero-dorsal, and posterior rods being fenestrated only in their outer part, a considerable portion at their basis remaining unfenestrated; further the postero-lateral processes ("auricularfortsätze") are "äusserst kurz, breit und abgerundet." In my Echinodermenlarven der Plankton Expedition, as well as in Nordisches Plankton I have accordingly given these characters for this larva, no later observations having been made on it. The observations of Krohn are, however, not very detailed, and especially it is an important objection that the reared larvæ did not reach a very advanced stage. There must be several other Spatangoid larvæ in the Mediterranean, and as their specific characters are not sufficiently known we have no guarantee that the pelagic larvæ which Krohn re- 
ferred to Spatangus purpureus did really belong to that species. It was therefore very satisfactory to me to get the opportunity of rearing the larva of this species during my stay in Plymouth. It proved to be very easy to rear; the larvæ developed normally and reached their full size in the course of three weeks. The fertilization was made on the $23 \mathrm{rd}$ June ; on the 14th July the larvæ had all their processes developed, and the first sign of the metamorphosis (formation of the oral disc) had appeared. Unfortunately I cannot utilize this culture for a complete description of the larval skeleton, on account of the mishap explained above. Still some notes can be given which may prove sufficient for the certain recognition of the larva.

The shape of the fully formed larva is, as shown in Figure 14, that of the typical Spatangoid larva. It is especially to be noticed that the postero-lateral processes are long and slender (and a little posteriorly directed) as in other Spatangoid larvæ, not short, broad, and rounded as stated by Krohn. If it is, upon the whole, really the $S$. purpureus larva which Krohn has observed, it must then have been in a stage where the postero-lateral processes are just about to appear. According to his description, "Beobachtungen über Echinod. larven," p. 209, quoted in Echinodermenlarven der Plankton Expedition, the body shape of the larva. is rather complicated, with lobes and folds; in reality it is quite simple, without folds, as seen in the figure. It is, then, most probable that the larva described here by Krohn is not at all the $S$. purpureus larva, but the larva of another Mediterranean Spatangoid-which species cannot be ascertained at present. The only thing in the description of Krohn which agrees with the $S$. purpureus larva is the extraordinary length of the postoral, postero-dorsal, and, especially, the posterior processes. Very probably also the other processes will attain a greater length than shown in the figure. They are a little swollen at the point, which is conspicuously coloured with red pigment. A feature to be noticed about the larva is a groove inside the posterior transverse chord (Fig. 14) ; the meaning of this groove is unknown to me.

The skeleton is, as shown by Krohn, characterized by the fact that the fenestrated rods (postoral, postero-dorsal, and posterior) have no holes in their basal part; in the posterior rod it is, however, only quite a short part which is unfenestrated (Fig. 15), in the other rods the unfenestrated part may really be as long as figured by Krohn ("Über die Larve von Spatangus purpureus," Taf. VII, 2-3) ; characteristic also is the widened basal part of the antero-lateral rods (cf. Krohn, Taf. VII, 5). The most important point to settle in regard to the skeleton is the structure of the 
postero-lateral rod, which appears to be the part of the skeleton of the Spatangoid larva which affords the best specific characters. Unfortunately the only information I can give of it is that to be found in

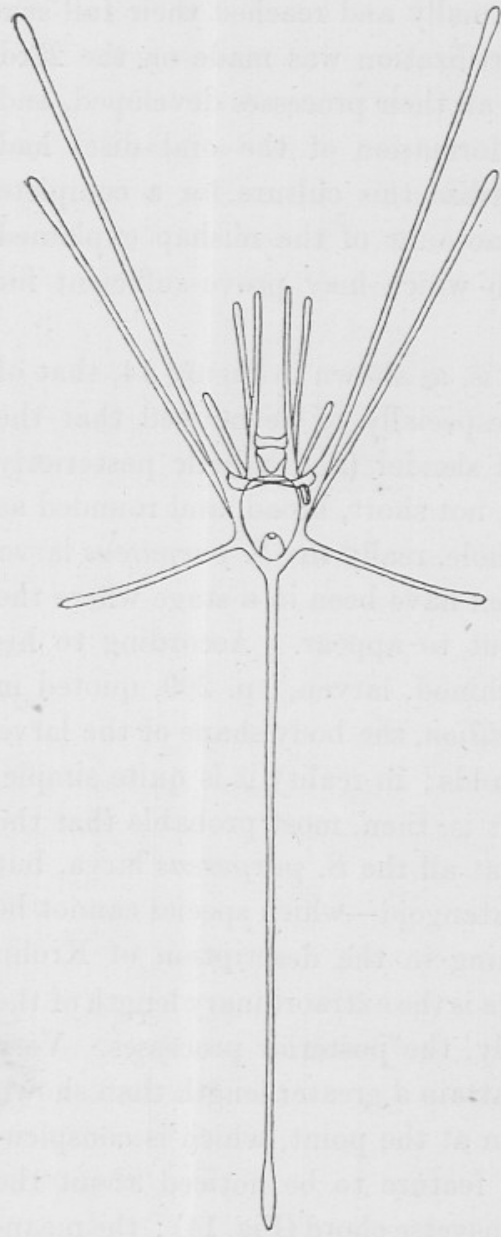

Fig. 14.

Fig. 14.-Echinopluteus of Spatangus murpureus, three weeks old. $35 / 1$.



Fig. 15.

Fig. 15.-Part of the skeleton of the Echinopluteus of Spatangus purpureus. $p$, Posterior rod, ; $p l$, postero-lateral rod. $275 / 1$.

Figure 15. It is seen that its basis is not widened, and that its edges are serrated. Apparently it will be found to resemble that of the larva of Echinocardium cordatum (cp. Echinodermenlarven der Plankton Expedition, Taf. IX, 7).

The total length-processes included-is ca. $3.5 \mathrm{~mm}$., not $6 \mathrm{~mm}$. as 
Krohn gives it (op. cit., p. 209). It may be mentioned that from the appearance of the first processes, the posterior and postoral, it ceases rotating round its longitudinal axis. The first appearance of the posterolateral processes occurred on the 7th July, viz. in the two weeks old larva ; the antero-dorsal processes are the latest to appear-when the metamorphosis is beginning, in ca. three weeks old larvæ.

All processes, except the preoral, have a conspicuous red point; otherwise there are scattered red pigment cells on the body and processes, more numerous on the body and the posterior process, and at the frontal edge.

\section{VI.-Holothuria nigra.}

The development and the larval form of this species being hitherto quite unknown, I was very anxious to try fertilizing and rearing it. Ripe specimens were found together with such as were very far from having ripe sexual products. The difficulty was with the eggs; I never found a specimen with the eggs quite ready for fertilization. The nucleus was nearly always large, and while in the other Echinoderms used by me for fertilization the eggs were found to ripen after having been some hours in sea-water (the nucleus disappearing), this was not the case in Holothuria nigra; even after the eggs had been twenty-four hours or more in the sea-water only in quite a small percentage of them had the nucleus disappeared. The eggs are a beautiful red, with a radiating striated membrane, as is known in other Holothurians.

On the 24th June I tried fertilization, having found a female in which more eggs than usual had no visible nucleus. (Ripe males were easy to get.) The fertilization was, contrary to my expectations, successful; on the next day I found that ca. 200 eggs were apparently in cleavagebut the cleavage looked so irregular that I was nearly certain the development was not going on normally. However, these eggs were isolated, and on the 27th I found that they had developed into swimming gastrulæ. On the 1st July the vibratile chord had begun to differentiate, and on the 4th July they had developed into a typical Auricularia, with a star-shaped spicule at the posterior end. Beyond this stage the development had not proceeded when I left Plymouth, and as I had only very few larvæ left, I could not get material of it preserved later on. It appears from this that there will be no difficulty in rearing the larvæ of this species, contrary to Selenka's experiences with Holothuria tubulosa ("Zur Entwicklung der Holothurien. [H. tubulosa und Cucumaria NEW serIes, - vol. X. No. 1. NOVEMBER, 1913. 
doliolum.] Ein Beitrag zur Keimblättertheorie," Z.w.Zool. XVII, 1876). The difficulty here is to get the eggs in condition for fertilization.

The Auricularia of $H$. nigra very much resembles that of $H$. tubulosa, as figured by Selenka (op. cit., Taf. X, 9). The colour is the same as shown there, only I find it more equally distributed in the vibratile chord; also there are some patches of this colour over the body, and especially in the posterior end. Unfortunately I did not make a drawing from a living specimen; the few preserved specimens are not so well preserved that it would be worth giving a figure therefrom, and the spicule has been dissolved. Still, the information given here will be quite sufficient for recognizing the larva, especially in the waters off Plymouth, where no other Holothuria species occurs with which it could be confounded.

Judging from the larva, H. nigra must be nearly related to H.tubulosa. The suggestion made in my Echinodermenlarven der Plankton Expedition (p. 15), that the larva of $H$. tubulosa will prove to have a spicule at the posterior end in later stages, is very much supported by the fact that such a spicule is found in the larva of $H$. nigra. A similar calcareous spicule is also found in Auricularia stelligera (Joh. Müller's "Auricularia mit Kugeln"); but it has besides some pink elastic spheres, of which there is no indication in the larvæ of $H$. nigra and tubulosa, so that the $A$. stelligera would not seem to be very closely related to these larvæ. 